\title{
HAUNTED HOUSES, HORROR LITERATURE AND THE SPACE OF MEMORY IN POST-DICTATORSHIP ARGENTINE LITERATURE ${ }^{1}$
}

Silvana Mandolessi

In his well-known essay 'The Uncanny' (1919), Freud posits an intrinsic relationship between the experience of what he terms 'the uncanny' and spatiality. According to Freud's definition, the uncanny occupies a fundamental position in that it manifests itself in the alteration of a space which, having hitherto been perceived as familiar, becomes the opposite: an unhomely space inhabited by otherness; a space which loses its familiar quality because it has been invaded and altered. The uncanny is thus linked to the affect with which a subject relates to a given space: to the affect with which a space is charged and to the transformation of this affect into another - predictably its opposite.

At the same time, the category of space, which in Freud's essay may in principle seem easy to define, is revealed to be more complex and difficult to grasp. There exists, for example, an intimate interdependence between space and time which renders it more complex. According to Freud's formulation, space and memory appear to be intrinsically linked, as there is an invasion of a past experience into the present which manifests itself in the uncanny. Different temporalities coincide in the same place while the boundary between past and present becomes blurred, thus rendering space an ambiguous category. The ambiguity or indecipherability, uncertainty and impossibility of assured knowledge are in fact the most remarkable characteristics pertaining to the sensation of the uncanny. This intellectual uncertainty and the impossibility of dissociating what is familiar and what is not form the nucleus of the experience that Freud seeks to describe.

Even though Freud's formulation of the uncanny deals with individual subjectivity, the same characteristics are relevant when describing the political experience of terror, the focus of this paper. There is a spectrum of emotions related to fear which comprises, among others, the 
uncanny, horror and terror. There also exists a long history of trying to adequately distinguish what nuances each of these emotions.

As David Punter points out, the main difference between 'horror' and 'terror' is precisely the political characteristic of the latter. In his entry on 'Terror' in The Handbook to Gothic Literature Punter emphasises that terror has had, and indeed continues to have, a direct connection with the socio-political field. In this sense, it is no coincidence that the roots of Gothic fiction (the genre of terror par excellence) ca be traced back to the period of revolution in Europe; one of its manifestations being the French 'Reign of Terror' ( $L a$ Terreur). While horror has to do with what frightens or disgusts, terror is at once deeper and less total, offering the dual possibility of submerging us in political abjection and emerging from it having gained a certain sense of self (Punter, 1998, p.235). In short, the affective impact of horror is more direct, cruder and also simpler, whereas the affective impact of terror is more profound, indirect, potentially more complex and capable of affecting subjectivity, thus involving a socio-political dimension.

Returning to the aforementioned link between the affect of terror and the importance of spatiality as established by Freud, I will approach political terror in terms of space, focusing on the dictatorship that gripped Argentina between 1976 and 1983. My analysis will focus on literature that narrates this socio-political experience. Thirty years on, the topic is still omnipresent in Argentine literature, albeit now written for the most part by a generation that did not directly experience it. What such literature processes, therefore, are the effects of terror and its memory. In recent novels that deal with the effects of state terrorism, what catches the reader's attention is an extended use of conventions drawn from the fantastic and gothic genres in order to narrate the social and subjective experiences of disappearance. This will not seem so strange if we consider that the closest cultural representation to the figure of the disappeared is that of the ghost: someone in between life and death; a liminal figure located between presence and absence, past and future. Jacques Derrida suggests that 'the spectral is that which is neither alive nor dead' (Wolfreys, 2002, p.x, original emphasis). The disappeared are indeed spectres of Argentine collective memory. Following Avery Gordon's line of argument it is possible to reaffirm that, despite every effort to produce concrete knowledge of the disappeared and dispel their spectral status, spectrality is still the form in which they inhabit the collective memory. This is frequently approached in narrative terms via the classic literary genre of terror. Comparing historical events with the well-known 
fantastical story The Monkeys' Paw, by William Wymark Jacobs, the narrator of Guillermo Saccomanno's novel 77 (2008) states:

Our reality was no less terrifying than this tale. The dictatorship referred to its victims as desaparecidos [disappeared]. The prefix "des" suggested that, in the event that they were found, what these mothers were going to receive would then be aparecidos [appeared]. However many explanations and psychological theories were invented to overcome the grief, the disappeared would always be phantoms circling them just as they circled the Plaza demanding that pink building for their appearance. Perhaps terror was the most apt genre to recount our national history. (Saccomanno, 2008, p.65, my translation and emphasis)

The genre of the fantastic - and that of the gothic in particular — has often been conceived as a genre of evasion; a genre scarcely entering into contact with reality. The images of ghosts, supernatural events, haunted houses, monstrous creatures and exotic locations suggest, in principle, a type of narrative that would not be well suited to reflection upon political violence. However, numerous critics have questioned the classification of the gothic as a genre of evasion, drawing attention instead to its capacity to refer to the socio-political reality in which the work is produced, even though this reference may not be made by means of the most direct or transparent realism. Furthermore, since the publication of Derrida's influential work Specters of Marx (1993) the notion of spectrality and in particular the concept of 'haunting' - direct derivatives of the gothic tradition - have taken on a dimension which transforms them into critical instruments with which to think politically. To this effect, Andrew Smith affirms that 'whilst it would be banal to state that ghosts bring the past back to life, spectrality does become a means through which to explore history' (Smith, 2007, p.153). The metaphor of ghosts that literally bring the past into the present transforms them into a powerful image of what a culture has tried to silence within itself: this oblique character of the ghost lingers by signaling what a culture can express only in indirect terms. In line with what certain critics have termed the 'spectral turn', I would like to concentrate here on the representation of two paradigmatic spatialities in post-dictatorship Argentine literature; paradigmatic in the sense that they symbolize two key elements - or experiences under the regime established by the Argentine dictatorship. The first is the affectivity of terror and the second is the affectivity evoked by absence (not any absence, but rather a particular experience of absence resulting from the repressive technique of disappearance). I would like to put forward the hypothesis that spatially these two affectivities express 
themselves in opposite ways: in the first case, the terror that dominates the social body is rendered figurative by means of a maximum concentration of space which in literature is represented by the haunted house; in the second, the experience of absence that causes disappearance. In contrast to the maximum spatial concentration that terror provokes, disappearance is identified with evanescence or dissolution - within the space and of the space itself. More specifically, disappearance is determined by the impossibility of assigning a particular location to the body. Absence and spatiality mutually convoke one another, which is why spatiality becomes a key category for understanding - and on occasions 'coming to terms with' - the functioning and effects of military dictatorship.

\section{The Haunted House}

The military dictatorship in Argentina carried out its repressive practices via the installation, across the entire national territory, of more than three hundred concentration/extermination camps. The victims were kidnapped in their houses or on the street and taken to one of these centres. Once inside, they were deprived of everything and subjected to torture in order to extract information and subsequently 'disappeared'. In her examination of the way in which these camps functioned, Pilar Calveiro underlines that one of the keys to understanding the regime's oppression is the fact that these spaces were not - as was the case in other repressive regimes - located outside and far away from the city, but rather within the confines of urban public space (Calveiro, 1998). She explains that the location of Clandestine Detention Centers (Centro Clandestino de Detención - CCD) in the heart of the city constituted an 'open secret':

The problem of the secret appears to be directly linked to the question of legality. The secret - what is hidden, and/or underground - is part of the centrality of power (...). The concentration camps were secret and so were the bodies interred Nomen Nominandum in the cemeteries. However, in order for the mechanism of disappearance to function, these secrets had to be open; such camps needed to be known about in order to disseminate the terror (...). Secrets which need to be known, albeit remaining unspoken, but which everyone knows. (Calveiro, 2006, pp.78-9, my translation.)

The neighbors knew and did not know what was happening there. They could hear voices, see fragments, but were not entirely sure about the crimes that were being committed. This mechanism was essential to spreading terror across the entire society. All space becomes contaminated with terror via the spectral presence of this 'secret' right in the middle of public space. Space which was once familiar now becomes haunted by the presence of a secret 
which threatens it inhabitants. Thus, the insertion of the concentration camp into the middle of the city does not effectively transform the entire city into a camp, but rather affectively transforms the relationship of the city to its inhabitants. The experience of this space becomes figurative in post-dictatorship novels as the closed space of a haunted house. The haunted house awakens wide-spread terror and the threat of feeling pursued in a closed space, from which it is impossible to escape; a sensation which is identified with the paranoia that terror produces. The classic or exotic haunted house does not appear in the novels to which I refer here, but rather in common spaces: ordinary houses, public spaces, such as schools, or larger spaces such as small provincial towns. They are, above all, spaces closed off in themselves, with no contact whatsoever with the outside. This lack of contact with the world outside is one of the characteristics that differentiates the welcoming quality of a familiar space from the oppressive character of a space of imprisonment. Contact with the outside world is not necessarily forbidden or closed off in a way that might indicate the fact that the house now represents a sign of threat rather than familiarity: it is the secret that inhabits it that is the center of gravity attracting its inhabitants, preventing them from leaving. The house possesses a blind centre, installs a conflict with such intensity that it causes everything outside to pale and dissolve. The space turns in on itself precisely because what should be outside has been situated inside, at the heart of the familiar.

La casa de los conejos (The Rabbit House) by Laura Alcoba (2008) is narrated from the point of view of a young girl and recounts her confinement, alongside her mother and other members of the Montoneros, inside a house in which they are all living secretly during the dictatorship. The girl lives with the fear of accidently betraying the secret of the house - the secret in this case being the existence of the house itself. Although she and her mother manage to escape, the house will eventually be blown up and those inhabiting it will die. In Ciencias morales (Moral Sciences) by Martín Kohan (2007), the claustrophobic space is that of the renowned Colegio Nacional (one of Argentina's most prestigious public high schools) in Buenos Aires. Here, a similar plot is inverted: the space of the school shuts itself off in order to protect its pupils from being contaminated by the surrounding social chaos. A strict disciplinary regime is established, one which prevents any contact with this exterior space which the conservative forces within the school perceive to be dangerous. Other novels reproduce the pattern of closed space, extending it from the home or school to a town. In $E l$ colectivo (The Bus) by Eugenia Almeida (2009), the setting that is chosen to narrate the oppressive atmosphere of the dictatorship is a small town in the province of Córdoba in the 
1970s. If small towns are usually oppressive in themselves, then this image is reinforced because the town's contact with the world outside is all but cut off. The only bus to pass through the town, thus linking it with other towns, is stopped by the military because they are looking for a couple, deemed to be 'subversives', who are supposedly hiding there. Confinement and silence are the two topics that dominate the narration. In the end the couple is found and murdered and thus the town returns to 'normality'. A similar, albeit more complex, image forms the basis for Carlos Gamerro's El secreto y las voces (The Secret and the Voices) published in 2002. This novel is also set in a small town - this time in the province of Buenos Aires - and describes the search undertaken by Fefe, who years later returns to the town in which she spent her childhood in order to find out what really happened to the town's only 'desaparecido', who turns out to be her father, something the reader only discovers at the end. In this case, the oppressive atmosphere is derived from the reconstruction of the voices, rather than the silence which reigns over the characters in $E l$ colectivo. The protagonist speaks to each of the town's inhabitants who, instead of holding their tongues, are keen to recount what happened. These voices, which despite their differences end up speaking in unison, become oppressive in precisely the opposite way to the silence discussed above: because they do not hold their tongues and because the chorus of murmurs repeats itself from different angles, what emerges is a discourse of complicity in which everyone ends up being responsible for the disappearance of someone innocent.

As can be observed, the pattern of closed space is repeated in the novels. Furthermore, in each case this closed space functions in the same way as that of a haunted house, which can be read as a metaphor for the way in which social space functions during a military dictatorship. Each one of these spaces is a haunted space, because behind the appearance of a normal course of life lurks the secret of a crime.

In La casa de los conejos, the house is blown up because someone reveals its whereabouts, and this someone turns out to be one of the members who is hidden in the house. In Ciencias morales the supposedly unpolluted space of the school, which claims to protect its students from social violence, is revealed to be inhabited by violence on the inside. This inner violence in the novel comes from the school's Chief Custodian, who is in charge of looking after the safety of its members but who rapes the Hall Monitor. El colectivo tells of how the relationships between the neighbors are shot through with old hatreds, social inequalities and misunderstandings that do not have anything to do with the 'subversive' couple and, as 
certain secrets remain incomprehensible to the reader even as the novel draws to a close, they determine the life of the town and render its inhabitants incapable of reacting. This is a social space that is 'contaminated' beyond what happens with the disappeared couple. Finally, the town in El secreto y las voces is an illustration of civilian complicity with the military dictatorship. As the protagonist discovers, the whole town knew that his father would become one of the 'disappeared', because the policeman in charge told everyone in the hope that someone would prevent it happening, but no one did anything. The imminent disappearance of the main character's father was once again an open secret; a secret of ambiguous character that associated it with generating terror.

These novels may all stage terror, but I would particularly like to point out that spatiality introduces an important distinction with regard to a common idea that terror comes from being at the mercy of alien forces, from the possible threat that otherness poses. In contrast to this classic conceptualisation, according to which an Other - or that which is other invades our innocent and unpolluted space, the space of the haunted house in contrast indicates that the source of terror lies inside the social body and is the uncontrollable eruption of underlying social conflicts. The home - a metaphor for public space - collapses, not because of the invasion and violence exercised upon it by an alien force, but rather because it becomes terrifying with the weight of unresolved crimes which have been silenced for so long. The theme of the haunted house invites the reader to renounce any simplistic version of political conflict and revise the historical genealogies that lead to terror in the present, albeit in a different way in each of these texts. The idea that the 'outside' does not exist and that the origin of conflict needs necessarily to be traced inside the house - the social body prevents comfortable readings of society as innocent; simple spectators of two alien forces that debate with one another beyond the bounds of their responsibility.

\section{The Materiality of Absence}

The second form of spatiality does not specifically concern literary thematics — such as the haunted house - but the manner in which the affective experience of absence is inscribed into a space. If the experience of absence — and the affectivity that it incites — is obviously present in the death of a loved one, in the case of forced disappearance it takes on an intensity that is exceptional, being derived from the uncertainty surrounding the location of the body. Traditionally, the ritual of burial enables the body of the deceased to be attributed a resting place. Giving him or her a place means that the domains of the living and the dead can be 
differentiated and enables the place of the living to be protected and cocooned. But in the case of disappearance, the impossibility of granting a place to the absent body 'extends' this absence to all spaces. A painting by South African artist William Kentridge illustrates this effectively: in it there is a small figure with his back turned, facing an inscription that occupies almost all the space of the painting, and which reads ' $[\mathrm{h}] \mathrm{er}$ absence filled the world.' Gabrielle Schwab sees a perfect emblem of traumatic loss in Kentridge's painting because

the mood of Kentridge's drawing captures the affects that aggregate around disappearances: the absence becomes a totalizing force, swallowing all life and energies. It is as if the world is gradually emptied out by the disappeared, leaving nothing behind but the ghostly traces of past memories. Disappearance drains the world's vitality and color, creating the death-in-life quality of a shadow world. (Schwab, 2013, p.3)

Absence cannot therefore be considered simply as the opposite of presence. Lars Frers insists on this in his article 'The Matter of Absence' (Freres, 2013, pp. 433-4) in which he argues that absence, or rather the experience of absence, is always a relational phenomenon. A person has to miss something or someone in order for him, her or it to be absent. There was a farm here and now there is not; someone was here with me in this place, but died of cancer two years ago and now I am here alone. The perception of absence thus emerges in the comparison with the way in which space and time are lived and, in particular, from the difference between past and present within the same space. It is in this difference that absence becomes presence.

The question posed by much post-dictatorship fiction is how to represent - make visible or present - this absence, in particular the affective aspect of absence that results from disappearance and its principle characteristic: the impossibility of assigning a place (of rest) to the body. It is no coincidence that many works of fiction resort to a spatial matrix in their attempt to represent and reflect upon the affectivity induced by disappearance. This absence that is present - or omnipresent - translates spatially in many works of fiction in their representation of paradoxical spaces and, by not occupying any place, ends up occupying all space. Among these, it is worth mentioning La costa ciega (The Blind Coast) by Carlos María Domínguez (2010), Memorias del río inmóvil (Memories of the Immobile River), by Cristina Feijoó (2001), El lugar perdido (The Lost Place) by Norma Huidobro (2007) or Purgatorio (Purgatory), by Tomás Eloy Martínez (2008). 
The very titles of these novels highlight these paradoxical and anomalous spaces: because they are anthropomorphised (La costa ciega); because what should flow is in fact static (Memorias del río inmóvil); because the lost space is in reality the only one that is permanently inhabited (Huidobro's novel); or because they call directly upon spaces that have traditionally been represented as intermediary, suspended and generally associated with their not being easy to inhabit, as is the case in Purgatorio. These novels may all stand out because they grant space a central role, but one in particular stands out because it positions space at the centre of the scenario, converting it into a significant instrument by which the feeling of absence that is typical of disappearance is translated symbolically: Los planetas (The Planets) by Sergio Chejfec, published in 1999, in which the narrator who is simply called ' $S$ ' recalls his disappeared friend ' $M$ ' by remembering the walks they took together across the city. The geography of the city is visited and revisited through this memory and the perception of space becomes one of the principle objectives of the narration, alongside the relationship that these friends have with their surroundings - a defamiliarised space that is rendered strange. In this sense, Chejfec's novel belongs to what Wolfgang Hallet would call 'fictions of space' or 'spatial fictions'; fictions that thematise perception and spatial practice as a key element in their narration (Hallet, 2009, p.108).

Los planetas neither reconstructs the terror of the era nor investigates the socio-political causes of violence. Instead, it takes the form of an intimate narrative evoking time shared between friends and above all dwelling on the effect that M's disappearance has had on S. Space in the novel is not only the stage on which events take place, but itself becomes a specific theme. It becomes the key to measuring, or giving meaning to, the effects of disappearance. As S affirms, this is because the defining feature of disappearance is spatial: the impossibility of assigning a place to an absent body. The narrator states in one passage of the novel:

If the fatefulness of his absence exaggerated what had happened, the lack of a space, a site, as I said, made it incomprehensible. It might have been a matter of just one person, as was the case, but it was infinite in scope. (Chejfec, 2012, p.108)

The impossibility of precisely locating an absent body distorts, in various ways, the manner in which space is both perceived and inhabited. One of the ways in which this is thematised 
in the novel is through the idea of disorientation or spatial dislocation: things are not in the place in which they seem to be. They occupy one space, while also occupying another.

A second metaphor for spatial distortion and dislocation is that of disorientation; the impossibility of orientating oneself correctly in space. This can be read as a means of expressing the loss not only of spatial but also cultural coordinates (Hallet, 2009, p.82). According to Hallet, this undermines a human's ability to 'cognitively to map its position in a mappable external world' (Jameson cited in Hallet, 2009, p.82); a loss of cultural coordinates brought on, in this case, by the catastrophe of meaning established by the practice of forced disappearance. ${ }^{2}$ The novel habitually adopts the strategy of attributing the impossibility of self-orientation to disappeared friend $\mathrm{M}$, rather than describing it as a sensation experienced by S. S states that

M had always had a poor sense of direction; this led to a complete detachment from the geography of the city. It took him the same torturous effort to locate a point five blocks away, as fifty. (...) To his mind, space was a question without a clear answer. (Chejfec, 2012, p.23, my emphasis)

What remains significant is that, in his consciousness, space is 'a question without a clear answer'.

The most significant spatial anomaly is, however, without a doubt that which refers to the dialectic between absence and presence. Against the abundance of a realist text - and by this I mean of a space filled with meaningful objects - the city in Los planetas appears in contrast to be marked by absence. That is not to say that the objects (buildings, streets, houses) are not there - although Chejfec often situates the reader in places that are unpopulated and uninhabited (liminal spaces, vacant lots, roads, parks) — but rather that the most tangible or monumental presence is not one marked by abundance, but in the most radical way by emptiness. In a passage from Los planetas, $\mathrm{S}$ describes a football stadium that occupies the center of the neighborhood in which $\mathrm{M}$ once lived. Rather than filling the space and acting as a point of reference, the stadium is portrayed as a hole in the real:

[D]espite its size, the shadow it cast, and the matches that were played within it, the field was not really the center of anything. The noise that swells up from the grounds and the silence - despite the match-beneath which everything seems submerged and that allows no indication from inside to pass, demonstrate the ambiguity of the gaping space, at once receptive and manifest, that is the stadium. The funereal silences that fill the air when the stands suddenly fall quiet imbues [sic] its rudimentary architecture with a sense of absence proportional, though inversely, to its size. At first one thinks 
about it and says, for example, [sic] Well of course the stadium is the center of the neighborhood, the place that gives life to its surroundings, the building that gives the neighborhood its character, and things like that, referring to the green patch of turf toward which all the surrounding streets and sidewalks seem to be orientated. But the opposite is actually true - the crust of the field is precisely that: an empty space erected on an arbitrary site. (Chejfec, 2012, p.31, emphasis in the original)

In another passage from the novel, the narrator states: 'Years later that same place (...); that same place would contain M's sudden absence as it had once contained his body, as contradictory as this might sound' (Chejfec, 2012, p.32).

In other words, the city is presented as an anomalous space paradoxically inhabited by a vacuum. Rosemary Jackson comments on fantastical spaces: '[u]nlike marvellous secondary worlds, which construct alternative realities, the shady worlds of the fantastic construct nothing. They are empty, emptying, dissolving' (Jackson, 1981, p.45). The text does not construct anything, or perhaps a more appropriate analysis would be that instead it builds nothingness. It bestows a place upon emptiness which in turn gives $M$ his place.

The act of giving $\mathrm{M}$ his place equates to a testimony of absence, or to producing an absence in a way that renders it visible, tangible; in a way in which it can be experienced as a loss without becoming diluted over time. There was a time when $\mathrm{M}$ and $\mathrm{S}$ would walk together through a shared space: the city of Buenos Aires. The here and now of the narration takes place in this same city, albeit one that is irremediably other. Los planetas obsessively works to bear testimony to the tenuous difference between two cities which relies on this relationship to lived space and time. Space not only becomes a witness and metaphor merely the static mise-en-scène within which the action takes place — but the figure of absence. Its distortions and spatial anomalies enable representation of the distortions and anomalies that the practice of terror and forced disappearance under the military dictatorship in Argentina imprinted upon society.

To conclude, when space in these novels is read figuratively, a series of spatial anomalies come to the fore, drawing attention to the significance of the following point: that both the haunted house and the spectral spaces of absence amount to a symbolization of affectivities and affect. Affect is not synonymous with sentiment or emotion, because as the theory of affect has clearly demonstrated, it transcends subjectivity: it does not presuppose a subject that is at the centre (Gregg and Seigworth, 2010). In this sense, to speak about the affect of 
terror or the affect exuded by absence does not imply that a subject is terrorised or experiences loss on a private level: rather it refers to forces and intensities that traverse bodies without necessarily emerging from them. Therefore, the affectivities of terror or the absence that such spaces conjure up are political, enabling us to reflect in a more complex manner upon the intensities and forces that become mobilised - or indeed inversely become immobilized — via the bodies that make up social space.

\section{BIBLIOGRAPHY}

Alcoba, Laura. 2008. La casa de los conejos translated by Leopoldo Brizuela. Buenos Aires:Edhasa.

Almeida, Eugenia. 2009. El colectivo. Buenos Aires: Edhasa.

Calveiro, Pilar. 2006 [1998]. Poder y desaparición: los campos de concentración en Argentina. Buenos Aires: Colihue.

Chejfec, Sergio. 2012. The Planets translated by Heather Cleary. Rochester: Open Letter.

Domínguez, Carlos M. 2010. La costa ciega. Buenos Aires: Mondadori.

Feijoó, Cristina. 2001. Memorias del río inmóvil. Buenos Aires: Clarín/Alfaguara.

Frers, Lars. 2013. 'The Matter of Absence'. Cultural Geographies, 20/4: 431- 45.

Gamerro, Carlos. 2002. El secreto y las voces. Buenos Aires: Norma.

Gatti, Gabriel. 2011. Identidades desaparecidas: Peleas por el sentido en los mundos de la desaparición forzada. Buenos Aires: Prometeo.

Gordon, Avery F. 2008 [1997]. Ghostly Matters: Haunting and the Sociological Imagination. Minneapolis: University of Minnesota Press.

Gregg, Melissa. and Gregory J. Seigworth eds. 2010. The Affect Theory Reader. Durham and London: Duke University Press.

Hallet, Wolfgang. 2009. 'Fictions of Space: Zeitgenössische Romane als fiktionale Modelle semiotischer Raumkonstitution'. In Raum und Bewegung in der Literatur. Die Literaturwissenschaften und der Spatial Turn edited by Wolfgang Hallet and Birgit Neumann. Bielefeld: Transcript, 81-115.

Huidobro, Norma. 2007. El lugar perdido. Buenos Aires: Alfaguara.

Jackson, Rosemary. 1981. Fantasy: The Literature of Subversion. London: Methuen.

Kohan, Martín. 2007. Ciencias morales. Barcelona: Anagrama.

Martínez, Tomás E. 2008. Purgatorio. Buenos Aires: Alfaguara.

Mulvey-Roberts, Marie ed. 1998. The Handbook to Gothic Literature. Basingstoke: Palgrave Macmillan.

Punter, David. 1998. 'Terror'. In The Handbook to Gothic Literature, edited by Marie Mulvey-Roberts Basingstoke: Macmillan.

Saccomanno, Guillermo. 2008. 77. Buenos Aires: Planeta.

Smith, Andrew. 2007. 'Hauntings'. In The Routledge Companion to Gothic, edited by Catherine Spooner and Emma McEvoy. London and New York: Routledge, 147-54.

Wolfreys, Julian. 2002. Victorian Hauntings: Spectrality, Gothic, the Uncanny and Literature. Basingstoke: Palgrave Macmillan. 
${ }^{1}$ The research leading to this chapter has received funding from the European Research Council under the European Union's Seventh Framework Program (FP/2007-2013)/ERC Grant Agreement n²40984, "NOT."

${ }^{2}$ For further discussion of forced disappearance as a 'catastrophe of meaning' see Gatti (2011) Identidades desaparecidas: Peleas por el sentido en los mundos de la desaparición forzada. 